\title{
Analisis Deskriptif Career Contruction Mahasiswa Tingkat Akhir
}

\author{
Ria Setyawati, Tuatul Mahfud, Bambang Jati Kusuma \\ Program Studi Tata Boga, Politeknik Negeri Balikpapan \\ Email: ria.setyawati@poltekba.ac.id
}

\begin{abstract}
ABSTRAK
Lulusan pendidikan vokasi memiliki orientasi pada kesuksesan karir di bidang keahlian masing-masing. Pengalaman belajar dan magang kejuruan menjadi modal utama untuk mempersiapkan kesiapan karir mahasiswa. Penelitian ini merupakan penelitian ex-post facto dengan populasi mahasiswa tingkat akhir yang telah mengikuti Praktek Kerja Lapangan dengan jumlah sampel 291 responden. Penelitian ini menggunakan analisis deskriptif dengan mengeksplorasi tentang career contruction. Hasil analisa penelitian menyatakan bahwa mahasiswa tingkat akhir memiliki kematangan konsep diri kejuruan, mampu mengeksplorasi informasi tentang pekerjaan, memiliki keputusan untuk berkomitmen pada pilihan pekerjaan dan memiliki persiapan penerapan pilihan sesuai bidang keahliannya. Dapat dinyatakan bahwa sebenarnya mahasiswa tingkat akhir telah memiliki kemampuan dalam menentukan karirnya dimasa mendatang. Kematangan karir merupakan kematangan tiap individu untuk mampu membuat pilihan karirnya dan tidak hanya sekedar dapat memilih pekerjaan saja.
\end{abstract}

Kata Kunci: Kontruksi Karir, Kesiapan Karir, Pendidikan Kejuruan

\section{ABSTRACT}

Vocational education graduates have career success orientation in their fields expertise. Learning experiences and vocational internships are the main capital to prepare students' career readiness. This study is an ex-post facto study with a population of the last semester students who have participated in the On the Job Training with a sample of 291 respondents. This study used descriptive analysis by exploring career construction. The results of the research analysis stated that the last semester students have vocational self-concept maturity, can explore information about work, have a decision to commit to work choices, and have prepared for implementing choices according to their fields expertise. Therefore, it can be concluded that the last semester students can determine their future careers. Career maturity is the maturity of each individual to be able to make their career choices, and it is not only choosing about the job.

Keywords: Career Construction, Career Readiness, Vocational Education

\section{PENDAHULUAN}

Pengembangan dan persiapan karir bagi lulusan pendidikan vokasi merupakan isu penting untuk menggambarkan sejauh mana kesuksesan pendidikan vokasi untuk membentuk kesiapan karir bagi peserta didik.Alasan mendasarnya karena secara filosofis pendidikan kejuruan atau vokasi merupakan pendidikan yang menyiapkan peserta didik untuk terampil pada keahlian tertentu.Sehingga wajar jika lulusan pendidikan vokasi memiliki ekspektasi tinggi terhadap perolehan kerja atau kesuksesan karir setelah lulus.Selain itu, mendapatkan pekerjaan sesuai dengan kompetensi yang dimiliki merupakan harapan bagi setiap lulusan pendidikan vokasi.Dengan demikian, informasi tentang konstruksi karir lulusan pendidikan vokasi sangat penting diperoleh untuk mengetahui kesiapan karir mereka. 
Menurut Savickas(1997), kajian konstruksi karir telah semakin menonjol dalam kajian psikologi karir. Teori Career Construction merupakan model konstruksi karir dari adaptasi yang menjelaskan proses konstruksi karir selama rentang hidup seseorang melalui hubungan antara dimensi adaptivity, adaptability, adapting dan adaptation. Oleh karena itu, model adaptasi konstruksi karir menggambarkan interaksi karakteristik pribadi yang stabil, kapasitas psikologis, perilaku karir, dan hasil karir dan mengasumsikan bahwa hasil karir yang optimal (adaptation results) akan dicapai oleh perilaku karir yang memadai (adapting responses), yang difasilitasi oleh kapasitas psikologis (adaptability resources) dan ciri-ciri pribadi (adaptive readiness). Kajian career construction adalah kajian penting karena merupakan dasar untuk praktek pengembangan karir, dan memberikan wawasan konselor karir profesional tentang bagaimana membantu klien mereka membuat pilihan kejuruan dan membangun kehidupan kerja yang sukses dan memuaskan. Menurut Savickas et al. (2018), model pengukuran career construction terdiridari crystallizing a vocational self-concept, exploring information about occupations, deciding to commit to an occupational choice, dan preparing to implement that choice.

Dalam konteks ini, lulusan pendidikan vokasi khususnya mahasiswa politeknik memiliki orientasi pada kesuksesan karir di bidang keahlian mereka masing-masing. Pengalaman belajar dan magang kejuruan menjadi modal utama untuk mempersiapkan kesiapan karir mereka. Seharusnya, lulusan pendidikan vokasi memiliki kesiapan karir yang baik setelah lulus khususnya karir yang sesuai dengan pilihan pendidikan kejuruan mereka. Namun, sayangnya studi sebelumnya menemukan kesenjangan antara teori dan temuan di lapangan. Salah satunya, studi yang dilakukan oleh Indana(2018) mengungkapkan bahwa sebagian besar (90\%) lulusan Sekolah Menengah Kejuruan di Trenggalek (Indonesia) tidak bekerja pada bidang pendidikannya. Secara spesifik, lulusan sekolah perhotelan yang seharusnya telah memiliki kematangan pilihan karir di bidang perhotelan, namun justru lebih memilih jenis pekerjaan lain (Chuang \& Dellmann-Jenkins, 2010; Richardson, 2009, 2010; Song \& Chathoth, 2011). Selain itu, menurut Richardson(2010), sebanyak 50\% siswa telah memikirkan untuk bekerja di luar industri perhotelan. Penyebabnya diantaranya, pandangan negatif yang didapatkan dari pengalaman kerja sebelumnya dan ketidakpercayaan terhadap prospek karir di bidangnya (Kusluvan \& Kusluvan, 2000; Richardson, 2009, 2010). Kesenjangan temuan ini menjadi permasalahan yang serius kenapa lulusan pendidikan vokasi masih belum matang pilihan karir mereka.

Banyak studi yang telah mengkaji tentang pentingnya pembentukan career construction, namun sejauh ini masih ditemukan kesenjangan teori dan praktik.Oleh karena itu, penelitian ini bertujuan untuk mengeksplorasi career construction mahasiswa politeknik yang mencakup kematangan konsep diri kejuruan(crystallizing a vocational self-concept), eksplorasi informasi tentang pekerjaan (exploring information about occupations), keputusan untuk berkomitmen pada pilihan pekerjaan (deciding to commit to an occupational choice), persiapan untuk menerapkan pilihan (preparing to implement that choice). Selain itu, studi ini juga menguji model pengukuran career contruction mahasiswa politeknik.

\section{METODE PENELITIAN}

Penelitian ini merupakan penelitian ex-post facto. Populasi dalam penelitian ini yaitu mahasiswa Politeknik yang telah selesai mengikuti program magang atau Praktek Kerja Lapangan (PKL).Rincian populasi dan sampel penelitian ini ditunjukkan pada Tabel 2. Penentuan jumlah sampel dalam penelitian ini menggunakan acuan tabel sample size dari Isaac dan Michael (1981) dengan taraf kesalahan 1\%. Jumlah sampel yang diperoleh yaitu berjumlah 265 responden.Selanjutnya, untuk mengantisipasi terjadinya kesalahan pengisian angket oleh responden dan berdampak pada munculnya data outlier, maka jumlah sampel ditambah sebesar 
$10 \%$ (26 sampel). Dengan demikian, total sampel yang terlibat dalam pengisian kuesioner yaitu sebanyak 291 responden. Sedangkan teknik sampling yang digunakan dalam penelitian yaitu menggunakan proportional random sampling.

Tabel 1. Distribusi Populasi dan Sampel Penelitian

\begin{tabular}{|c|c|c|c|c|}
\hline No & Nama Program Studi & $\begin{array}{l}\text { Jumlah } \\
\text { Populasi }\end{array}$ & $\begin{array}{l}\text { Jumlah } \\
\text { Sampel }\end{array}$ & Tambahan \\
\hline 1 & Prodi D3 Tata Boga & 48 & 30 & 3 \\
\hline 2 & Prodi D3 Divisi Kamar & 15 & 10 & 1 \\
\hline 3 & Prodi D3 Teknik Mesin Alat Berat & 70 & 43 & 4 \\
\hline 4 & Prodi D3 Teknik Elektronika & 87 & 54 & 5 \\
\hline 5 & Prodi D3 Teknik Listrik & 25 & 16 & 2 \\
\hline 6 & Prodi D3 Teknik Sipil & 71 & 44 & 4 \\
\hline 7 & $\begin{array}{l}\text { Prodi D4 Teknik Rekayasa Jalan } \\
\text { Jembatan }\end{array}$ & 24 & 15 & 2 \\
\hline 8 & Prodi D3 Perbankan dan Keuangan & 64 & 40 & 4 \\
\hline \multirow[t]{2}{*}{9} & Prodi D4 Akuntansi Perpajakan & 21 & 13 & 1 \\
\hline & Total & 425 & 265 & 26 \\
\hline
\end{tabular}

Pengumpulan data masing-masing variabel dilakukan dengan cara self- report. Mahasiswa memberikan penilaian persepsi mereka terhadap career construction. Instrumen penelitian diadaptasi dan dikembangkan dari hasil penelitian sebelumnya tentang career construction(Savickas et al., 2018). Skala pengukuran penelitian ini menggunakan skala Likert dengan lima alternatif jawaban yang terdiri dari sangat setuju $=5$, setuju $=4$, agak setuju $=3$, kurang setuju $=2$, tidak setuju $=1$.

Analisis data dalam penelitian ini menggunakan analisis statistic deskriptif untuk mengetahui gambaran deskriptif tentang kematangan konsep diri kejuruan(crystallizing a vocational self-concept), eksplorasi informasi tentang pekerjaan (exploring information about occupations), keputusan untuk berkomitmen pada pilihan pekerjaan (deciding to commit to an occupational choice), persiapan untuk menerapkan pilihan (preparing to implement that choice).

\section{HASIL DAN PEMBAHASAN}

\section{Identitas Responden}

Hasil analisis identitas responden yang ada, menunjukkan bahwa responden dapat diketahui rata-rata mahasiswa berusia 21 tahun. Dengan didominasi mahasiswa yang rata-rata perempuan dari 8 program studi. Rata-rata mahasiswa memiliki sekolah asal dari SMA dengan prosentase $62,9 \%$ dan $37 \%$ dari SMK, untuk saat ini peminat untuk melanjutkan pendidikan di politeknik lebih banyak dari SMA, Siswa lulusan SMK lebih banyak yang memilih untuk bekerja.

\section{Hasil Analisa Deskriptif}

\section{Kematangan Konsep Diri kejuruan}

Pada indikator kematangan konsep diri kejuruan terdapat 6 butir pengembangan, antara lain; 1) Mahasiswa memahami jenis karir yang sesuai dengan kepribadiannya, diperoleh jawaban tertinggi sebanyak $56 \%$ menyatakan setuju dan jawaban terendah $0,7 \%$ tidak setuju, sedangkan sisanya $28,4 \%$ sangat setuju, $13,8 \%$ agak setuju dan $1,1 \%$ menyatakan sangat tidak setuju. 2) Mahasiswa mengetahui potensi dirinya, diperoleh jawaban tertinggi 57,5\% setuju dan jawaban terendah $0,7 \%$ tidak setuju, sedangkan sisanya $29,5 \%$ sangat setuju, $11,3 \%$ agak setuju dan $1,1 \%$ sangat tidak setuju. 3) Mahasiswa dapat menentukan hal apa yang penting untuk mendukung pilihan karirnya, diperoleh jawaban tertinggi sebanyak 59,3\% menyatakan setuju dan jawaban terendah $0,7 \%$ tidak setuju, sedangkan sisanya $29,8 \%$ sangat setuju, $9,1 \%$ agak 
setuju dan 1,1\% sangat tidak setuju. 4) Mahasiswa mengetahui bagaimana orang lain menilai dirinya, diperoleh jawaban tertinggi 49,5\% menyatakan setuju dan jawaban terendah 3,3\% sangat tidak setuju, 3,3\% tidak setuju, sedangkan sisanya $21,1 \%$ agak setuju dan $22,9 \%$ sangat setuju. 5) Mahasiswa dapat bergaul dengan orang yang dia sukai, diperoleh jawaban tertinggi sebanyak 55,6\% menyatakan setuju dan jawaban terendah $1,1 \%$ tidak setuju, sedangkan sisanya 31,3\% sangat setuju, 10,5\% agak setuju dan 1,5\% sangat tidak setuju. 6) Mahasiswa berusaha mencari tau hal apa yang menjadi minatnya, diperoleh jawaban tertinggi sebanyak $56 \%$ menyatakan setuju dan jawaban terendah $0,7 \%$ tidak setuju, sedangkan sisanya $34,9 \%$ sangat setuju, 7,3\% agak setuju dan 1,1\% sangat tidak setuju.

Berdasarkan 6 pernyataan tersebut indikator kematangan konsep diri kejuruan dengan rekapitulasi sebagai berikut:

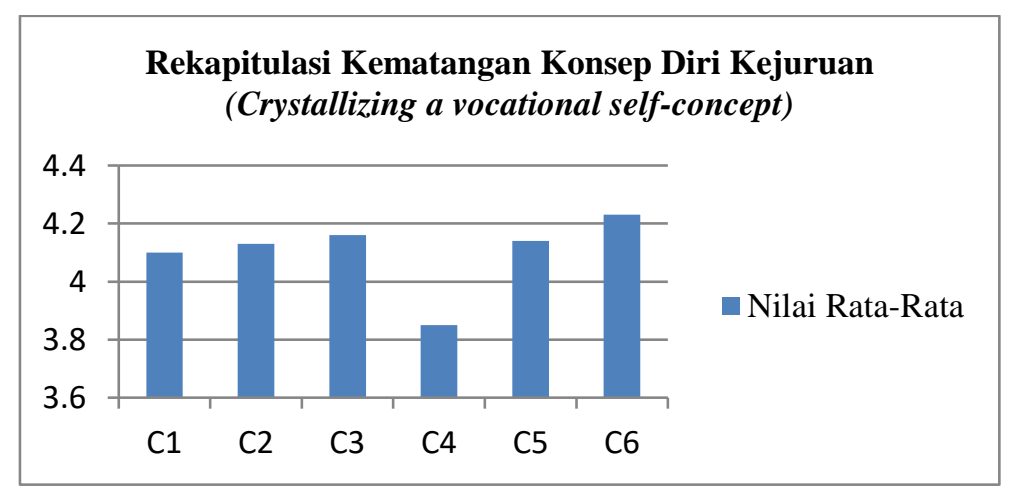

Hasil rekapitulasi tersebut dapat diketahui bahwa kematangan konsep diri kejuruan mahasiswa tingkat akhir memiliki jawaban rata-rata di atas 4 . Dengan adanya kematangan konsep diri kejuruan yang telah dimiliki dapat diketahui bahwa mahasiswa tingkat akhir mampu memilih dan mempersiapkan untuk menentukan pilihan karirnya. Sehingga nantinya ketika bekerja dapat bekerja secara profesional karena telah mengetahui kemampuan ataupun kekuatan dalam dirinya sendiri. Kesesuaian antara individu dengan pekerjaan dan bagaimana sikapnya dalam pengambilan keputusan dalam pemilihan pekerjaan merupakan konsep kematangan kejuruan menurut Crities (1969).

\section{Eksplorasi Informasi Tentang Pekerjaan}

Pada indikator eksplorasi informasi tentang pekerjaan terdapat 3 butir pengembangan, antara lain; 1) Mahasiswa mempelajari berbagai jenis pekerjaan berbeda yang memungkinkan menjadi pilihan karir, diperoleh jawaban tertinggi sebanyak $57,1 \%$ menyatakan setuju dan jawaban terendah $0,7 \%$ tidak setuju, sedangkan sisanya $1,1 \%$ sangat tidak setuju, $14,2 \%$ agak setuju dan 26,9\% sangat setuju. 2) Mahasiswa membaca berbagai hal tentang jenis pekerjaan di masa depan, diperoleh jawaban tertinggi sebanyak 59,6\% menyatakan setuju dan jawaban terendah $1,1 \%$ sangat tidak setuju, sedangkan sisanya $1,5 \%$ tidak setuju, $14,5 \%$ setuju dan 23,3\% sangat setuju. 3) Mahasiswa berusaha mencari informasi jenis pekerjaan yang cocok, diperoleh jawaban tertinggi sebanyak $59,6 \%$ menyatakan setuju dan jawaban terendah $1,1 \%$ sangat tidak setuju, sedangkan sisanya $8 \%$ agak setuju, 31,3\% sangat setuju.

Berdasarkan ketiga pernyataan tersebut indikator eksplorasi informasi tentang pekerjaan dengan rekapitulasi sebagai berikut: 


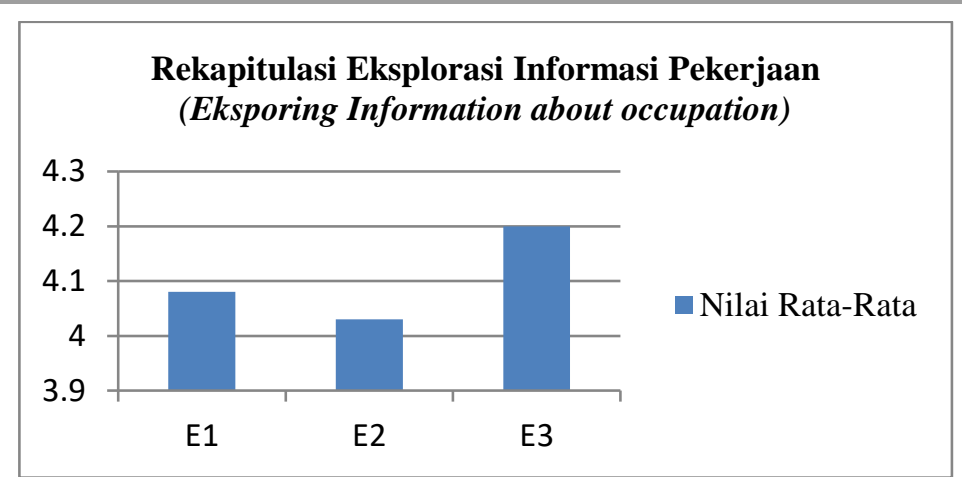

Hasil rekapituasi eksplorasi informasi tentang pekerjaan memiliki jawaban rata-rata 4. Secara deskriptif dapat dikatakan bahwa mahasiswa mampu mempelajari jenis pekerjaan berbeda yang memungkinkan menjadi pilihan karirnya, mampu membaca jenis pekerjaan di masa depan dan mencari informasi jenis pekerjaan yang cocok. Hal ini sesuai pendapat dari Greenhaus dan Callanan (2006) yang menjelaskan eksploarsi karir merupakan salah satu upaya pengumpulan informasi tentng diri dan pengetahuan tentang lingkungan, dengan tujuan untuk membina kemajuan dan pengembagan karir.

\section{Keputusan Untuk Berkomitmen Pada Pilihan Pekerjaan}

Pada indikator keputusan untuk beromitmen pada pilihan pekerjaan terdapat 5 butir pengembangan; 1) Mahasiswa berani mengambil keputusan untuk menentukan pekerjaan, diperoleh jawaban tertinggi sebanyak 59,3\% menyatakan setuju dan jawaban terendah $0,7 \%$ sangat tidak setuju, sedangkan sisanya 1,1\% sangat tidak setuju, 9,1\% agak setuju dan 29,8 sangat setuju. 2) Mahasiswa dapat menemukan pekerjaan yang sesuai dengan bidangnya. 3) Mahasiswa dapat memilih jenis pekerjaan yang membuatnya puas, diperoleh jawaban tertinggi sebanyak 59,6\% menyatakan setuju, dan jawaban terendah $1,1 \%$ tidak setuju, sedangkan sisanya 1,5\% sangat tidak setuju, 11,6\% agak setuju dan 26,2 sangat setuju. 4) Mahasiswa dapat menyusun cara untuk dapat bekerja sesuai dengan pilihannya, diperoleh jawaban tertinggi $61,1 \%$ setuju dan jawaban terendah $1,1 \%$ sangat tidak setuju, $1,1 \%$ tidak setuju dan sisanya 9,1\% agak setuju dan 27,6\% sangat setuju. 5) Mahasiswa dapat meyakinkan diri sendiri, bahwa dirinya memilih pekerjaan yang tepat, diperoleh jawaban tertinggi $63,3 \%$ menyatakan setuju dan jawaban terendah $0,4 \%$ tidak setuju dan sisanya $1,5 \%$ sangat tidak setuju, 7,3\% agak setuju dan $27,6 \%$ sangat setuju.

Berdasarkan kelima pernyataan tersebut indikator keputusan untuk berkomitmen pada pilihan pekerjaan sebagai berikut:

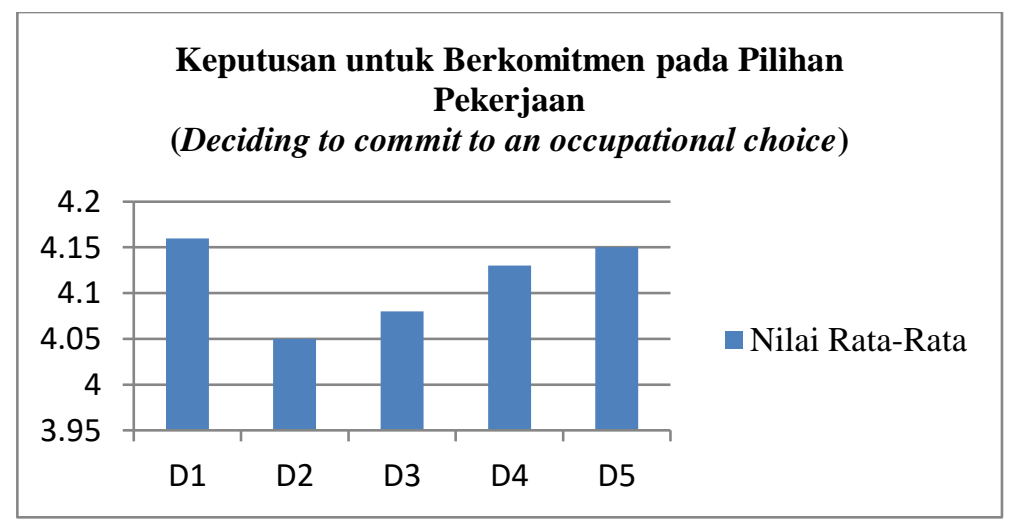


Hasil rekapitulasi keputusan untuk berkomitmen pada pilihan pekerjaan mahasiswa dapat diketahui bahwa jawaban rata-rata 4. Secara deskriptif mahasiswa mampu mengambil keputusan untuk menentukan pekerjaan, menemukan pekerjaan yang sesuai dengan bidangnya, dapat memilih jenis pekerjaan yang mebuatnya puas dan dapat menyakinkan diri bahwa dirinya mampu memilih pekerjaan yang tepat. Memiliki sikap berani mengambil keputusan untuk berkomitmen pada pilihan karir merupakan hal yang penting dalam mengembangkan karir nantinya ketika sudah terjun ke dunia industri. Dalam hal ini menurut hasil penelitian Ballout (2009) menyatakan bahwa komitmen karir berdampak terhadap kesuksesan karir seseorang. Dengan adanya komitmen pada pemilihan pekerjaan Niu (2010) menyatakan bahwa faktor penting yang dapat membanbantu seseorang atau individu bertahan pada pekerjaan tertentu dalam waktu yang cukup lama demi mengembangkan ketrampilan khusus yang telah dimiliki.

\section{Persiapan Penerapan Pilihan}

Pada indikator persiapan penerapan pilihan terdapat 4 butir pengembangan; 1) Mahasiswa berusaha menemukan peluang untuk mendapatkan pelatihan dan pengalaman yang dibutuhkan, diperoleh jawaban tertinggi sebanyak $60 \%$ menyatakan setuju dan jawaban terendah $0,4 \%$ tidak setuju dan sisanya 1,1\% sangat tidak setuju, $8 \%$ agak setuju dan 30,5\% sangat setuju. 2) Mahasiswa memulai pelatihan yang dibutuhkan untuk mendukung pekerjaan pilihannya, diperoleh jawaban tertinggi 56,7\% menyatkan setuju dan jawaban terendah $0,4 \%$ tidak setuju dan sisanya 1,1\% sangat tidak setuju, 11,6 agak setuju, dan 30,2\% sangat setuju. 3) Mahasiswa berusaha memenuhi kualifikasi untuk pekerjaan yang paling disukai, diperoleh jawaban tertinggi sebanyak 60,4\% menyatakan setuju dan jawaban terendah $0,4 \%$ tidak setuju dan sisanya $1,1 \%$ sangat tidak setuju, 5,8\% agak setuju dan 32,4\% sangat setuju. 4) Mahasiswa berusaha mendapatkan pekerjaan setelah menyelesaikan pendidikan atau pelatihan, diperoleh jawaban tertinggi sebanyak 55,3\% menyatakan setuju dan jawaban terendah $0,7 \%$ setuju, sisanya $1,8 \%$ sangat tidak setuju, $5,1 \%$ agak setuju dan $37,1 \%$ sangat setuju.

Berdasarkan kelima pernyataan tersebut indikator persiapan penerapan pilihan sebagai berikut:

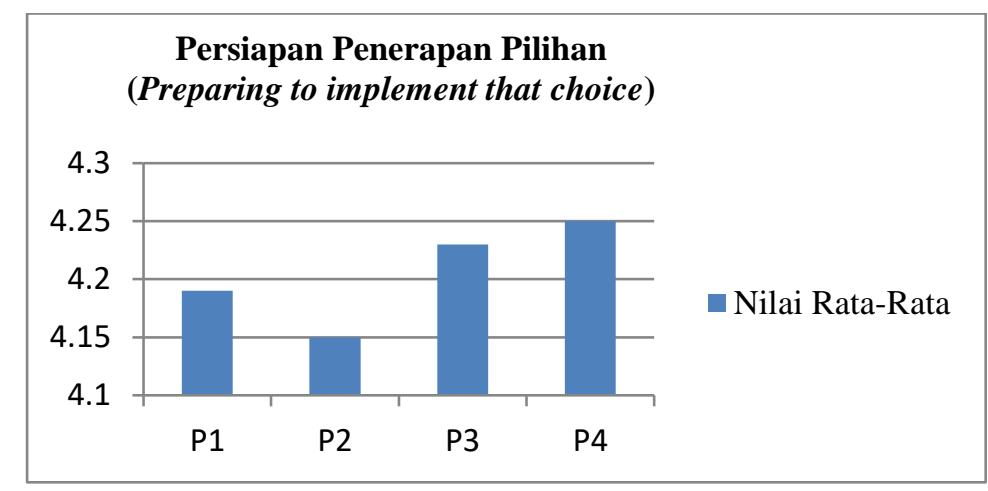

Hasil rekapitulasi persiapan penerapan pilihan mahasiswa dapat diketahui jawaban rata-rata 4. Secara deskriptif mahasiswa mampu berusaha menemukan peluang untuk mendapatkan pelatihan dan pengalaman yang dibutuhkan, dapat memilih pelatihan yang dibutuhkan sesuai pekerjaan pilihannya, mampu berusaha memenuhi kualifikasi untuk pekerjaan yang disukainya serta mahasiswa berusaha mendapatkan pekerjaan setelah menyelesaikan pendidikan atau pelatihannya. Berdasarkan beberapa indikator tersebut dapat dikatakan bahwa mahasiswa memiliki persiapan dalam merencanakan pilihan karirnya. Menurut Suherman (2009) menyatakan bahwa aspek dalam perencanaan karir diantaranya yaitu mengikuti pelatihan yang berkaitan dengan pekerjaan yang diinginkan, mengetahui kondisi pekerjaan yang diinginkan. 


\section{KESIMPULAN}

Berdasarkan hasil analisa di atas dapat dinyatakan bahwa sebenarnya mahasiswa tingkat akhir telah memiliki kemampuan dalam menentukan karirnya dimasa mendatang. Kematangan karir merupakan kematangan tiap individu untuk mampu membuat pilihan karirnya dan tidak hanya sekedar dapat memilih pekerjaan saja. Hal ini seperti yang diungkapkan Levinson (1998) bahwa kematangan karir merupakan aspek penting bagi individu dalam memenuhi kebutuhan akan pengetahuan dan ketrampilan untuk membuat keputusan karir yang cerdas dan realistik.

\section{DAFTAR PUSTAKA}

Ballot, H.I (2009). Carrer Commitment and Succes: moderating role of self efficacy. Career Development International, 14 (7), 655-670.

Crites, J. O. (1969). Vocational Psychology.The Study of Vocational Behavior and Development. New York: McGraw-Hill.

Greenhaus \& Callana. (2006) Encyclopedia Career Development. London: Sage

Indana, L. (2018). Job absorption evaluation of graduates of computer and informatics engineering study program in Trenggalek Regency (Indonesian version) [Yogyakarta State University]. http://eprints.uny.ac.id/60113/

Levinson, Edward M et.al (1998). Six Approaches to the Assesment of Career Maturity. Journal of Counseling ang Development (Vol.76 Iss.4 Fall 1998).p.475

Niu, H.J. (2010). Investigating the effects of self-efficacy on foodservice industry employees' career commitnent. International Journal of Hospitality Management. 29,743-750.

Richardson, S. (2010). Generation Y's perceptions and attitudes towards a career in tourism and hospitality. Journal of Human Resources in Hospitality \& Tourism, 9(2), 179-199. https://doi.org/10.1080/15332840903383855

Savickas, M. L. (1997). Career Adaptability: An Integrative Construct for Life- Span, LifeSpace Theory. The Career Development Quarterly, 45(3), 247- 259. https://doi.org/https://doi.org/10.1002/j.2161-0045.1997.tb00469.x 